\title{
"May Allah Not Let You Experience Another Sorrow": Condolence Strategies Used by Lecturers Who Are Native Speakers of Arabic L1 toward Their Colleague Who Is Native Speaker of Hebrew in Hebrew L2
}

\author{
Tareq Mitaib Murad \\ The Department of English, Sakhnin Academic College for Teacher Education, Sakhnin, Israel
}

\begin{abstract}
This research attempts to investigate the condolence strategies used by Arab native speakers (L1) towards a Hebrew (L2) native speaker in Hebrew (L2). Analysis of these strategies was almost based on strategies developed by a number of researchers (Olshtain and Cohen 1983; Elwood, 2004 and Yahia, 2010). The participants in this study were 85 Arab lectures who responded to a college condolence announcement which was addressed to a Hebrew native-speaker colleague who lost his daughter by e-mail. Frequencies and percentages were considered. The findings of the study revealed that the main condolence strategy used by the respondents was 'religion expressions' $(\mathbf{3 9 . 8 \%})$. This is attributed to the fact that the respondents transfer this strategy from L1 toL2. This strategy is affected by religion (Yahia, 2011). Other strategies such as acknowledgement of death, expression of sympathy, offer of assistance, future-oriented remarks, expression of concern, appreciation of the dead, direct condolence and others were less frequently used. The findings also showed that the females initiated more condolence utterances in the same response than males, however, the gender did not play an important role in the frequencies of the condolence strategies.
\end{abstract}

Index Terms — pragmatics, speech act, condolence strategies, L1 and L2, semantic formula

\section{INTRODUCTION}

Condolences are speech acts. Searle (1969) states the speech act of condolence is categorized as 'expressive'. Lotfollahi and Rasekh (2011) claim that this speech act is used to express the speaker's sorrow at the news of someone's death. On the hand, Yahia (2010) claims that formulas of condolence has not been fully explored, fortunately, most speakers are not called upon to express sympathy at someone's death. In fact, languages ca not be meaningfully studied in isolation from the context and culture. According to Lakoff (1973) "it is futile to set linguistic behavior apart from other forms of human behavior P. 303. As other speech acts condolence is also culturally different (Elwood, 2004). Many researchers have investigated the speech act of condolence and its cross-cultural differences (Elwood, 2004; Reza and Mostafa, 2012; Bernan, 2008; and others). The focus of these studies is on comparing the speech act of condolences between English and other languages. The aim of the recent study is to investigate the condolence strategies used by lectures Who are Arabic native speakers toward their colleague who is native speaker of Hebrew on the net as a response to the college announcement of the death of his in Hebrew.

\section{REVIEW OF RELATED LITERATURE}

\section{Speech Acts And Speech Act Of Giving Condolences}

Johnston (2008) States that " knowing a language means not just knowing its grammar and vocabulary but also knowing how to structure paragraphs and arguments and participate in a conversation the way the speakers of the language do" (P.7). According to Yule (1996), speech acts are speech functions that are realized by way of words. Speech acts include a wide range of functional units such as apologies, complements, requests, condolences, invitations and so on. Yule claims that being able to say the right thing to the right person at the right time would be great social accomplishment. Richard and Schmidt (2002) define pragmatics as "the study of the use of language in communication, particularly between sentences and the contexts and situations in which they are used" (P.412).

The knowledge of pragmatics plays a meaningful function in interlocutions between participants because pragmatics is the relation between language and its users. Levinson (1983: 284) asserts "conversation may be taken to that familiar predominant kind of talk in which two or more participants freely alternate in speaking, which generally occurs outside specific institutional setting like religious services, law courts, classroom and the like".

Bach and Harnish (1969) claim that speech acts are acts of communication. To communicate is to express a certain attitude, and the type of speech act being performed corresponds to the type of attitude being expressed. For example, a 
statement expresses a belief, a request expresses a desire, and an apology expresses a regret. As an act of communication, a speech act succeeds if the audience identifies, in accordance with the speaker's intention, the attitude being expressed.

Some speech acts, however, are not primarily acts of communication and have the function not of communicating but of affecting institutional states of affairs. They can do so in either of two ways. Some officially judge something to be the case, and others_actually make something the case. Those of the first kind include judges' rulings, referees' calls and assessors' appraisals, and the latter include sentencing, bequeathing and appointing. Acts of both kinds can be performed only in certain ways under certain circumstances by those in certain institutional or social positions.

Searle (1969) classified speech acts into five categories: assertive, directives, Commisives, expressive and declarations. While Austin (1962) classified the performative utterances into the following classes:

Behabitives: They make people express their feelings and attitudes such as thank, apologize, condole and congratulate.

Commisives: They make people commit themselves to do things like promise and vow.

Expositives: They make people bring about changes through their utterances such as resign and fire.

Exercitives: They try to get people to do things such as invite, order and permit. Verdictives: they tell people how things are like swear, insist and suggest.

According to Searle, (1969), speech act of condolence is related to the expressive classification, it is used to express the interlocutor's sorrow at the news of the death of someone. Yahia (2010) states that condolence phrases are designed to convey sympathy for the bereaved person. But as a general rule, the emotion behind the phrase is often more important than the wording itself. Yahia adds that condolences are formal expressions of sympathy offered to people after the death of a loved one. Many people are aware that it is very difficult to give condolence phrase without sounding slightly clichéd. Condolence expressions consists of utterances such as "sorry for your loss", "deepest sympathy" and many others. These condolence expressions are neutral enough to be appreciated for anyone regardless of religious beliefs. For believers in a concept of heaven and hell, one may want to refer the idea that he or she believes the diseased is in heaven. Phrases like "may Allah comfort the dead" and other references to religious belief should be tailored to specific religion (Yahia, 2010).

Hayajneh, (2009) claims that there are many areas where the notion of a separation between language and culture cannot be maintained, he adds that studying cultural aspects of the language such as beliefs, norms and religion may avoid errors and embarrassment.

Semantically, condolences have a social meaning which refers to the language use, this is to establish social relations and roles (Mwihaki, 2004: 133). He also adds that condolences are not just expressions of sympathy, they are also acts of encouragement.

Many researchers (Elwood,2004; Yahia, 2010; Lotfollahi and Rasekh, 2011; and others) classified the condolence responses according to semantic formula similar to Olshtain and Cohen's (1983) who found five types of semantic formulas for apologies. Accordingly, five patterns were found in the responses to the condolence situations in their studies:

a. Acknowledgement of the death: it includes certain interjections such as 'no' and 'oh'.

b. Expression of sympathy such as "I am participating in your sorrow".

c. Offer of assistance like "is there anything I can do?"

d. Future-Oriented remarks such as "try not to get depressed".

e. Expression of concern like "you must care for yourself".

These were the classical categories that most researchers based their investigating of offering condolences on, however, most of the researchers add other categories for responses that do not fit Olshtain and Cohen's (1983) semantic formula such as expression of empathy", "statement of lacking words", religion expressions", "expression of surprise", related questions', statement of not knowing", and others.

Elwood (2004) investigated the cross-cultural differences of expression of condolence between Americans and Japanese. She found differences between the way respondents of each language express their condolences.

Yahia (2010) investigated the ways that Iraqi express their condolences. He found that Iraqi people express their condolences in different ways and patterns, these patterns were influenced by culture, context, gender, education and age. However, these different expressions were affected by Islamic religion.

Lotfollahi and Rasekh (2011) investigated the cross-cultural differences of the condolence speech act between English and Persian. They found the condolence strategies used by Iranians were influenced by their religion.

Another similar study was conducted by Reza and Mostafa (2012). They investigated the condolences responses in English and Persian, They found that Persian responses were more celestial and collectivist in nature While English condolence responses are more terrestrial and individualistic.

Samavarchi and Allami (2012) conducted a socio-pragmatic study in which they studied the speech act of giving condolences by EFL learners in Iran. They found that some learners perform the speech act of condolence like their English counterpart. They also found that some of these learners performed this speech act like they do in Persian. In other words, these learners tend to transfer the act of condoling socio-culturally from their L1 to L2. 
Although many studies on the speech act of condolences have been conducted during the recent years, few of them focused on expressing condolences of native speakers of one language L1 to another speakers of other language L2 in the later language L2. That means, the condolences were made by the use of L2. The aim of the recent study is to investigate how Arab native speakers who live in Israel express their condolences to Hebrew native speakers in Hebrew through the net. In other words what condolences strategies are used by Arab native speakers in Hebrew.

\section{Methodology}

\section{Subjects}

The participants of the current study are 95 Israeli lecturers who teach at Sakhnin College for Teacher Education (TE) in Lower Galilee, in Northern Israel. The majority of lecturers are Arabic native speakers and some are Hebrew native speakers, but the students are Arabic native speakers, however, they speak Hebrew as L2 since Hebrew is the official language in Israel. The lecturers are teaching mathematics, English, special education, education and Arabic. They are holders of second and third degrees. The respondents are 10 lecturers who are Hebrew native speakers and 85 who are Arabic native speakers. The subjects are 53 males and 42 females. Their age is between 35-60. For the aim of this study, the researcher will collect the responses of Arab Lecturers, and ignore the responses of the lecturers who are Hebrew native speakers.

\section{Instrument}

The data of the current study was collected from responses to an e-mail message which was sent by the college management to a Hebrew native speaker colleague who lost his daughter in Hebrew. The translation of the electronic condolence message is "The college is participating in the sorrow of our colleague. We hope you will not experience another sorrow". The message was sent in Hebrew because the lecturer does not speak Arabic. 95 lecturers responded to this message to express their condolence to their mate. The responses were also in Hebrew and each lecture can see these responses in his email, because all of them clicked "Reply all". The researchers collected the responses of 85 (40 females and 45 males) Arab lecturers in order to analyze the condoling strategies used by Arab native speakers towards their colleague who is Hebrew native speaker, the language used was Hebrew which is considered as L2 for the respondents. 10 messages were ignored because they were written by lecturers who are Hebrew native speakers.

After taking the consent from the college management, the data was collected from 85 respondent to the condolence announcement in the college staff e-emails. All the respondents were lecturers at the College who are Arabic native speakers, but they used L2 (Hebrew) to express their condolence to their colleague who is a Hebrew native speaker and who lost his daughter.

The collected data was coded based on Olshtain and Cohen's (1983) with some modifications that were discussed with some experts in the field of pragmatics in the College to suit the current context. The unit of analysis was the responses produced by the respondents.

The data was categorized in nine categories as follow:

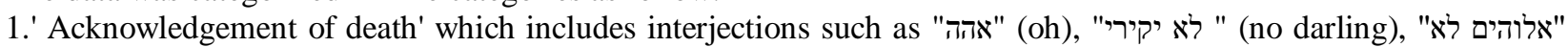
(No, God).

2. 'Expression of sympathy' such as "צני מצטער על אובדנך" (I am sorry for your loss), "צטי לי (I am sorry)," לשמוע את זה (I am sorry to hear that).

3. 'Offer of assistance' which covers responses like "אם תצטרך לדבר אני נמצאת "ניכור (If you need to say anything, I am ready), "איך אני יכול לעזור" (How could I help), "נם תרצה לדבר עם מישהו אני "נמצא (if you want to talk with anybody I am ready).

4. 'Future-oriented remarks' like "אני בטוחה שתעבור את זה" (be strong), (I am sure you will pass this), "החיים צריכים להמשך" (We ask God to protect you and your family). (אלוהים ישמור עליך ועל משפחתך" (Life should continue), "שלא תדע עוד צער" (May not you experience another sorrow).

5. 'Expressions of concern' which includes responses about the bereaved such as "מקווה שאתה בסדר" (I hope you are ok), "תשמור על האימא שלה בטח היא סובלת" (be patient), "תשזר בסבלנות", (Keep her Mom, sure, she is suffering.

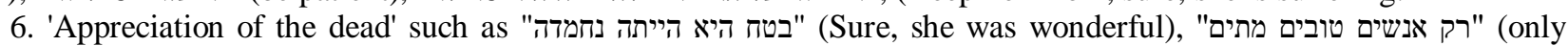
good persons die), "הייתה חבובה" (She was darling).

7. 'Religious expressions' like "אלוה" (ארוהים נתן, אלוהים לקח" (God gave, God took), "'אלוה ירחם עליה, (God mercy her), "שתהיה בגן עדן" (May her soul rest in paradise),

8. 'Direct condolence' which includes expressions such as "תנחומיי" (my condolences).

9. others such as 'sharing similar experience', statement of lacking words, 'expression of surprise' and 'related questions.

\section{Data Collection and Data Analysis}

The aim of the recent study is to examine the condolence strategies used by Arab College Lecturers towards their colleague who is Hebrew native speaker in Hebrew which is considered L2 for these lecturers. The strategies were written as a response to an e-mail announcement from the college to the Hebrew native-speaker who lost his daughter, and the lecturers responded to this announcement in the email by "Reply All". The respondents are 85 lectures who are Arab native-speaker, 40 females and 45 males, their age ranges 35-60. The total number of the condolence strategies 
made by the respondents is 153 . This means that some respondents made more than one condolence utterance in the same response. The number of utterance per respondent by gender is shown in Table 1.

TABLE 1

THE NUMBER OF UTTERANCES OF CONDOLENCE MADE By PARTICIPANTS BY GENDER

\begin{tabular}{|l|l|l|l|l|}
\hline & One strategy & Two strategies & Three strategies & Total \\
\hline Males & 26 & 14 & 5 & 45 \\
\hline Females & 8 & 20 & 12 & 40 \\
\hline Total strategies used & 34 & 68 & 51 & 153 \\
\hline
\end{tabular}

Table one shows the number of participants in the study. Moreover, it also shows the number of strategies made by each gender. The number of females is 40 . Eight females initiated one condolence utterance, 14 made two utterances in the same response, while twelve female participants initiated 3 utterances in the same reply. The total number of the condolence utterances made by females is 84 . On the other hand, the number of males are 45. 26 male respondents initiated one condolence utterance, while 14 made two utterances in the same response, 5 initiated three condolence utterance which consist of three different strategies according the semantic formula used in this study. The data shows that the occurrences of condolence utterances used by females are larger than their males counterparts. In other words the females initiated more condolence utterances than males.

\section{RESULTS}

After coding the data, The frequency and the percentage of semantic formulas used in this study were calculated. The Results are shown in Table 2. While Figure 1 shows the percentage of the strategies used by the respondents

TABLE 2

The Freouency and Percentage of CONDOLENCE StRATEgIES Used By the PARTicipants

\begin{tabular}{llll}
\hline & strategies & frequencies & Percentage \\
\hline 1 & Acknowledgement of the death & 23 & 15.3 \\
2 & Expression of sympathy & 20 & 13 \\
3 & Offer of assistance & 7 & 4.6 \\
4 & Future-Oriented remarks & 10 & 6.53 \\
5 & Expression of concern & 13 & 8.5 \\
6 & Appreciation of the dead & 5 & 3.2 \\
7 & Religious expressions & 61 & 39.8 \\
8 & Direct condolence & 5 & 3.2 \\
9 & Others & 9 & 5.87 \\
\hline
\end{tabular}

The researcher classified the condolence strategies into 9 categories. The categories are: (1) Acknowledgement of the death; (2) expression of sympathy; (3) Offer of assistance; (4)Future- oriented remarks; (5) Expression of concern; (6)appreciation of the dead; (7) Religious expression; (8) Direct condolence and (9) others which contains strategies such as 'sharing similar experience', statement of lacking words, 'expression of surprise' and 'related questions. As shown in Table 2.

Table 2 shows that 153 condolence utterances were initiated by the respondents, males and females. The 'religion expression' is the most frequent strategy used by the participants. It occurs 61 times 30 by males and 31 by females. Its percentage is 39.8\%. This strategy includes utterances such as "אלוהים לא ייתן ותדע עוד צער" (May Allah not let you experience another sorrow), "שיסלח לה אלוהים" (May God forgive her), "אלוהים נתן אלוהים לקות להודים" (God gave and God took)', "שתהי נשמתה בגן עדן" (May Allah rest her soul in Paradise), "ויברך אותה אדוני, זה הגורל שלוה" (God bless her, this is her destiny) and many others. This shows that the respondents are celestial and collectivist in nature (Reza and Mostafa, 2012), they are mostly Muslims and believe in God (Allah). The fact that this strategy is the most frequent one in this research could also be attributed to the age of the respondents. Their age ranges between 35 and 60, they are mature and as a result they, the researcher believes, are more religious. Bentahila and Davis (1989) state that Arab condolence strategies contain religious references. The participants transfer this strategy from their Arabic language L1 to the target language L2 (Hebrew). These utterances are frequently used in Arabic and the participants transfer it to Hebrew which may contain its own condolence utterances which are different from Arabic.

The next frequent strategy used by the participants is 'acknowledgement of dead ' and it includes utterances such as "צר לי על אובדנך"( I am sorry for your loss) and "מצער לשמוע את זה' , (I am sorry to hear that). This strategy occurs 23 times (15.3\%).

"The strategy "expression of sympathy" which consists of utterances like "הלב שלי איתך", (my heart is with you) and לא, איני מאמין (No, I do not believe). It occurs 20 times (13\%). 9 frequencies were initiated by males while 11 frequencies were made by females. So the frequencies do not reveal meaningful differences between males and females concerning the two strategies. "Offer of assistance" which contains utterances such as "אני יכול לעזור (how can I help) occurs 7 times (4.6). while

"appreciation of the dead" which includes utterances such as "היא הייתה נחמדה" (she was nice). It occurs 5 times (3.2\%). This strategy was less frequently used, because the participants, the researcher believes, do not know the dead 
or they do not want to talk about the dead for the sake of the addressee who lost his daughter. By using this strategy they were afraid they will increase his sorrow.

"Direct condolence" which contains utterances such as "תנחומי" (my condolences) is also less frequently used, It occurs 5 times (3.2\%). The researcher attributes the law frequency of this strategy to the fact that Arab native speakers who live in Israel are emotional, therefore, one utterance is insufficient for them to express their emotion towards the bereaved. Moreover, Performing the speech act of condolence in Arabic needs a sentence and not only a single word. The other strategies are: 'sharing similar experience', statement of lacking words, 'expression of surprise' and 'related questions. They occur 9 times. Figure 1 clarifies the percentage of the strategies used by the respondents of this study.

Figure 1: Distribution of strategies used by participants according to percentage
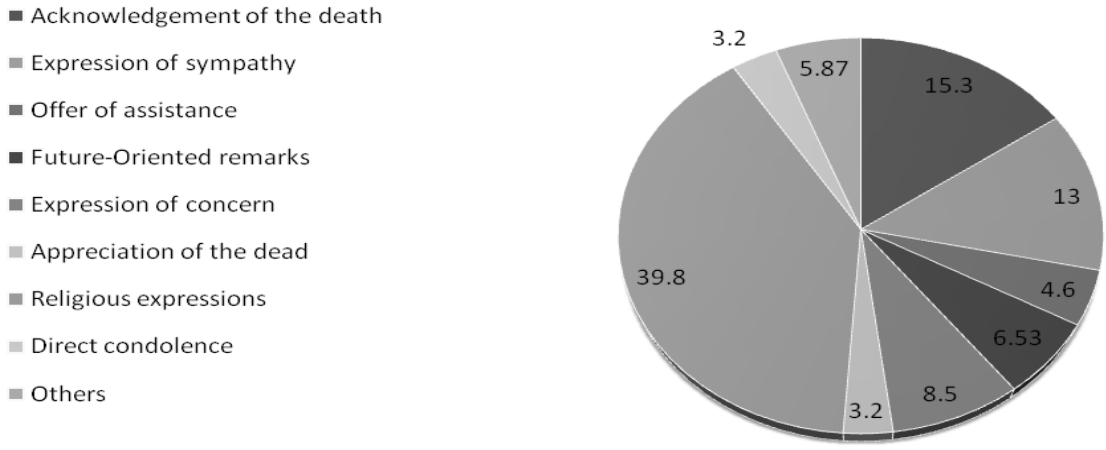

The frequencies do not reveal differences in the distribution of condolence strategies used by males and females as shown in the following table.

TABLE 3

THE FREQUENCY OF CONDOLENCE STRATEGIES BY GENDER

\begin{tabular}{llll}
\hline Strategy & Gender & & \\
\hline & Males & Females & Total \\
\hline Acknowledgement of the death & 10 & 13 & 23 \\
Expression of sympathy & 9 & 11 & 20 \\
Offer of assistance & 3 & 4 & 7 \\
Future-oriented Remarks & 5 & 5 & 10 \\
Expression of concern & 5 & 8 & 13 \\
Appreciation of the dead & 2 & 3 & 5 \\
Religious expressions & 30 & 31 & 61 \\
Direct of condolence & 2 & 3 & 5 \\
Others & 3 & 6 & 9 \\
\hline Total & 69 & 84 & 153 \\
\hline
\end{tabular}

Table 3 reveals that the males initiated 69 condolence utterances while females made 84 utterances, Although the number of the male participants was bigger than the males. The frequencies in this table do not show meaningful differences by gender except in the 'others' strategy which occurs only nine times. The occurrence of 'religious expressions" strategy is almost the same between males and females.

\section{CONCLUSIONS AND RECOMMENDATIONS}

This study attempts to investigate the speech act of condolence used by Arabic native speakers lecturers, who live in Israel and work in an Arab college for teacher education, towards their colleague, who is Hebrew native speaker and lives in Israel and works in the same college, in Hebrew. That means the participants are using L2 in expressing the speech act of condolence.

The findings show that the most frequent strategy used by the respondents is "religious expression" (39.8\%). This may be explained that the Arab condolence strategies may contain religious reference (Bentahila and Davis, 1989). In other words, the findings reveals that The Arab who live in Israel are celestial and collectivists rather than terrestrial and individualistic.

Moreover, the age of the respondents may have an effect on the frequency of this strategy. The age of the respondents ranges between 35 and 60. Arab eople at this age are usually mature and religious.

Moreover, The level of education of the respondents may also have an effect on the frequency of the strategies used in this research. The respondents' level of education is very high since they are all holders of second and third degree The responses were almost formal. 
The next frequent strategy used by the participants is "Acknowledgement of the dead" (15.3\%). Whereas, "appreciation of the dead" and "direct condolence" were the least frequent strategies used by the participants.

The findings also reveal that the participants transfer strategies from Arabic which is considered L1 to Hebrew which is considered L2. The religious expressions used by the respondents are frequently used in performing Arabic speech act of condolence.

Another important finding is that the gender does play an important role in the frequency of the condolence strategies. Males and females almost performed the same number of utterances in the same strategy.

The age of the participants has in important role in the distribution of the strategies. The participants' age is 35-60. Therefore, it is recommended to conduct another study with participants who are younger. Moreover, it is recommended to conduct another study to compare between the condolence strategies used by Hebrew and Arabic native speakers. Finally, it is also recommended to conduct a study to examine the participants' condolence strategies in Arabic (L1).

\section{REFERENCES}

[1] Austin, J. (1962). How to do things with words. Cambridge. Mass. Harvard University Press.

[2] Bach, K. and Harnish, R. M. (1979). Linguistic Communication and Speech Acts, Cambridge, Mass.: MIT Press.

[3] Bentahila, A and Davis, E. (1989). Culture and language use: A problem for foreign language teaching. IRAL, 27 (2), pp. 99112.

[4] Bernan, M. (2008). "Condolence book: Language and meaning in the mourning of Hillsborogh and Diana. Death studies. 32, pp 326-351.

[5] Elwood, K. (2004). "I am sorry: A cross cultural analysis of expression of condolence. Retrieved September, 2011 from http://dspace.wul.waseda.ac..jp.

[6] Hayajneh, A. (2009). The translation of stock expressions referring to Allah. Retrieved: October, 2011. From: www. Survey.ac.uk/politics/research/documents/cp-luaihayajheh.pdf.

[7] Johnston, B. (2008). Discourse analysis. Carlton: Blackwell Publishing.

[8] Lakoff, R. (1973). The logic of politeness or minding your P's and Q's. Chicago linguistics society, 9, Pp. 292-302.

[9] Levinson, S.(1983). Principles of pragmatics. Cambridge: Cambridge University Press.

[10] Lotfollah, B. and Rasekh, A. (2011). Speech act of condolence in Persian and English. Studies in Literature and Language. 3 , (3), pp. 139-145.

[11] Mwihaki, A. (2004). Meaning as use: a functional view of semantics and pragmatics. Swahili Forum, 11, 127-139.

[12] Olshtain, E. and Cohen, A. (1983). Apology: A speech act. In N. Wolfson and E. Judd (Eds.), Sociolinguistics and language acquisition, pp, 18-35. Cambridge: Newbery House publishing.

[13] Richards, J. C., and Schmidt, R. (2002). Dictionary of language teaching and applied linguistics. Pearson education: Longman.

[14] Reza, P. and Mostafa, M. (2012). Investigating condolences responses in English and Persian. International journal of Research Studies in language Learning. 2 (1), pp 39-47.

[15] Samavarchi, L. and Allami, H. (2012). Giving condolences by Persian EFL learners: A contrastive socio-pragmatic study. International Journal of English Linguistics. 2 (1), pp, 71-78.

[16] Searle, J. (1969). Speech Acts: An Essay in the Philosophy of Language, Cambridge: Cambridge University Press.

[17] Yahia, E. (2010). A study of condolences in Araqi Arabic with reference to English. Adab Al-Rafidayn, 57, pp. 47-70.

[18] Yule, G. (1996). The study of language. Cambridge: Cambridge University Press.

Tareq Mitaib Murad has been teaching English as a foreign language in high schools since 1990, and he has been teaching linguistic courses in Sakhnin College, Academic College for Teacher Education since 2001. Recently, he holds a position in the College: The Practicum General coordinator. Courses: Intro to linguistics, Second language acquisition, Morphology and Syntax, Semantics and pragmatics.

He has BA in English linguistic and literature from Ben-Gurion University, MA in English Linguistics from Haifa University, Pedagogical supervision from Machon- Mofet. TA and PhD in English curricula and Instructions from Yarmouk University. Research interests: pragmatics: speech acts, second/foreign language acquisition and task-based language teaching (TBLT).

The author has many publications in local and international Journals, the most recent of them are:

Murad, T. (2011). The Effect of Task-Based language Teaching on Developing Speaking Skills among the Palestinians Secondary EFL Students in Israel and Their Attitudes towards English. www.asian-efl-journal.com/Thesis/Thesis-murad pdf.

Murad, T., \& Shaalta, J . (2012). A contrastive Linguistic analysis between Arabic and English. In Arabic. Sakhnin college.

Murad, T. (2012).Apology strategies in the target language (English) of Israeli Arab EFL college students towards their lecturers of English who are also native speakers of Arabic. Studies of Language and Literature,4, (3). CSCanada. 